\title{
Influence of number of ingredients, use of supplement and vegetarian or vegan preparation on the composition of homemade diets for dogs and cats
}

\author{
Vivian Pedrinelli', Rafael Vessecchi Amorim Zafalon², Roberta Bueno Ayres Rodrigues², \\ Mariana Pamplona Perini ${ }^{2}$, Renata Maria Consentino Conti ${ }^{3}$, Júlio Cesar de Carvalho Balieiro ${ }^{3}$ and \\ Márcio Antonio Brunetto $1,2^{*}$
}

\begin{abstract}
Background: Homemade diets are a worldwide trend, and many recipes are currently available on websites but may not be considered balanced. This study aimed to evaluate if the number of ingredients, supplement, or vegetarian/ vegan-only ingredients included in a recipe influence the nutrient content of homemade diets for dogs and cats. Chemical analyses were performed on 75 diets for dogs and 25 for cats prepared according to websites' recipes, and minerals were analyzed by inductively coupled plasma optical emission spectrometry (ICP-OES).

Results: Canine diets that met fat requirements had more ingredients than those below recommendations. None of the cat diets met iron requirements, and feline diets that met requirements of manganese had fewer ingredients and those that supplied requirements of protein and sodium had more ingredients than the diets below recommendations $(p<0.05)$. Non-supplemented canine and feline diets had calcium and calcium:phosphorus ratio below recommendations $(p<0.05)$. Non-supplemented feline diets had lower sodium and iron, and zinc levels were below recommendation in diets for both species. Diets with animal products for dogs had higher levels of protein and zinc, although zinc was deficient in both groups, and there were higher amounts of crude fiber, magnesium, and manganese in vegetarian/vegan diets $(p<0.05)$. Diets with animal products for cats had higher levels of protein $(p=0.003)$, but there was a higher amount of crude fiber $(p=0.014)$ in vegetarian/vegan diets.
\end{abstract}

Conclusion: The number of ingredients and vegetarian/vegan preparation did not guarantee nutritional adequacy of diets, and the presence of supplement did not ensure a balanced diet.

Keywords: Canine, Feline, Home-prepared diet, Nutrient deficiency, Plant-based diet

*Correspondence: mabrunetto@usp.br

2 Pet Nutrology Research Center, Nutrition and Production Department, School of Veterinary Medicine and Animal Science, University of Sao

Paulo, Avenida Duque de Caxias Norte, 255, Pirassununga 13635-900, Brazil

Full list of author information is available at the end of the article

\section{Background}

To provide an adequate diet is an important part of pet care, and is essential to maintain the animal's health, improve quality of life, and increase the lifespan. Conventional diets, such as dry kibble or canned diets, are the most common types of diets fed to pets. However, there is a recent trend of feeding unconventional diets to dogs and cats, which includes homemade and vegetarian or 
vegan diets. A survey conducted in the United States and Australia [1] observed that $18 \%$ of dogs and cats were fed home-prepared diets, either as a part of the diet or as the main diet. A questionnaire survey [2] applied to more than 3000 owners of dogs and cats from 55 countries observed that more than $60 \%$ of pets were fed homemade food as a part of the diet, and $12 \%$ of dogs and $6 \%$ of cats were fed exclusively this type of diet.

Feeding unconventional diets, however, may put the animals at risk. The World Small Animal Veterinary Association has published a set of guidelines regarding nutritional assessment [3], which refer to nutritional evaluation as the 5th vital sign, along with temperature, pulse, respiration, and pain assessment. These guidelines also consider feeding an unconventional diet, such as raw, homemade, or vegetarian, a risk factor for dogs and cats.

The vegetarian and vegan population seems to be increasing worldwide. A survey in Brazil [4] indicated that between 8 and 14\% of the population evaluated is vegetarian, and a poll conducted in the United States [5] observed that $5 \%$ of the population surveyed is vegetarian and 3\% is vegan. In the United Kingdom, the vegan population was estimated to be only $0.25 \%$ in 2014 but increased to $1.16 \%$ of the population in 2019 [6]. India is the country with the highest percentage of vegetarianism: $28.4 \%$ of males and $29.3 \%$ of females do not eat meat [7]. The main motivations for humans becoming vegetarians or vegans are ethical and health concerns, environmental or sustainability reasons, and religion [8]. The owner's dietary choice can influence the type of food they choose to feed their dogs or cats. An online study [9] that included 3673 English-speaking pet owners observed that $6.2 \%$ were vegetarian and $5.8 \%$ were vegan. It was also observed that the majority of pets that were fed plant-based or vegan diets had vegan owners.

Regardless of being meat- or plant-based, homemade diets need to supply all nutrient requirements. One of the items that is considered essential in homemade diets for pets is the vitamin-mineral supplement, which guarantees that all nutrients are present in the diet since common ingredients do not provide all the nutrient requirements. If a diet is formulated without proper supplementation, it can be deficient, especially in minerals and vitamins $[10,11]$. However, even owners who have professionally-prescribed diets that contain supplements may omit this ingredient during preparation [12, 13]. A common practice among owners who feed homemade diets to their pets is the variety of ingredients in the formula, as they believe the frequent substitution of ingredients or the addition of more ingredients can ensure the diet meets the nutrient requirements, as opposed to "fixed" formulas [14]. This, however, may or may not be true, and depends on what ingredient is substituted or added.

Therefore, this study hypothesizes that vegetarian or vegan diets and diets without supplements will be nutritionally deficient and that the number of ingredients will not influence the nutritional adequacy of diets. This study aimed to evaluate the influence of the number of ingredients, the presence of supplement, or vegetarian/ vegan recipes on the nutrient content of homemade diets according to FEDIAF [15] and NRC [16].

\section{Results}

None of the diets were considered complete and balanced when compared to NRC [16] and FEDIAF [15], as previously published [10]. The recipes for dogs had a mean of 6.6 ingredients (range 4-14) and the recipes for cats used a mean of 9.1 ingredients (range 3-15). When mineral and vitamin-mineral supplements are not considered, recipes for dogs had a mean of 5.8 ingredients (range 3-12) and recipes for cats had a mean of 6.8 ingredients (range 3-13).

The results regarding the influence of the number of ingredients in diets for dogs are presented in Table 1 and for cats in Table 2. Canine diets that met fat requirements had more ingredients than those below recommendations. Feline diets that met requirements of manganese had fewer ingredients and those that supplied requirements of protein and sodium had more ingredients than diets below recommendations $(p<0.05)$. None of the cat diets met iron requirements.

Of the 75 recipes for dogs, $33.3 \%(n=25 / 75)$ did not indicate mineral or vitamin-mineral supplementation. If we consider the diets that only included salt, this percentage increases to $44.4 \%(n=33 / 75)$. Of the diets supplemented, $14.0 \%(n=7 / 50)$ only included calcium sources such as calcium carbonate or eggshell powder. The supplements that contained minerals indicated in the recipes for dogs were: salt $(n=15 / 75)$, veterinarian vitamin-mineral supplements of different brands $(\mathrm{n}=15 / 75)$, eggshell powder $(n=9 / 75)$, calcium carbonate $(n=8 / 75)$, dicalcium phosphate $(\mathrm{n}=3 / 75)$, potassium chloride $(n=2 / 75)$, zinc $(n=2 / 75)$, calcium citrate $(n=1 / 75)$, and vitamin-mineral supplement for children $(n=1 / 75)$.

Veterinarian vitamin-mineral supplements were not indicated in any of the recipes for cats. Only one recipe contained a children's vitamin-mineral supplement, 8 (32.0\%) did not include any type of mineral supplementation, and $2(8.0 \%)$ only included calcium sources. The supplements that contained minerals indicated in the recipes for cats were: salt $(n=10 / 25)$, calcium carbonate $(n=9 / 25)$, eggshell powder $(n=5 / 25)$, and vitamin-mineral supplement for children $(n=1 / 25)$. 
Table 1 Comparison of number of ingredients and nutrients per $1000 \mathrm{kcal}$ in diets for dogs

\begin{tabular}{|c|c|c|c|c|c|c|}
\hline & \multicolumn{6}{|l|}{ Number of ingredients } \\
\hline & \multicolumn{3}{|l|}{ NRC } & \multicolumn{3}{|l|}{ FEDIAF } \\
\hline & $\begin{array}{l}\text { Mean ingredient number } \\
\text { of diets below }( \pm S E)\end{array}$ & $\begin{array}{l}\text { Mean ingredient number } \\
\text { of diets above }( \pm \text { SE) }\end{array}$ & $p$ & $\begin{array}{l}\text { Mean ingredient number } \\
\text { of diets below }( \pm S E)\end{array}$ & $\begin{array}{l}\text { Mean ingredient number } \\
\text { of diets above }( \pm \text { SE) }\end{array}$ & $p$ \\
\hline Crude protein & $3.00 \pm 1.73$ & $5.86 \pm 0.28$ & 0.251 & $5.71 \pm 0.64$ & $5.85 \pm 0.31$ & 0.847 \\
\hline Ether extract & $4.50 \pm 0.61$ & $6.08 \pm 0.31$ & 0.042 & $4.50 \pm 0.61$ & $6.08 \pm 0.31$ & 0.042 \\
\hline Calcium & $5.81 \pm 0.33$ & $5.87 \pm 0.51$ & 0.919 & $5.82 \pm 0.31$ & $5.75 \pm 0.69$ & 0.884 \\
\hline Phosphorus & $4.84 \pm 0.61$ & $6.03 \pm 0.31$ & 0.112 & $5.74 \pm 0.38$ & $5.92 \pm 0.41$ & 0.757 \\
\hline Ca: $P^{1}$ ratio & - & - & - & $5.86 \pm 0.32$ & $5.86 \pm 0.91$ & 0.961 \\
\hline Potassium & $5.65 \pm 0.33$ & $6.21 \pm 0.51$ & 0.351 & $5.70 \pm 0.28$ & $8.00 \pm 1.41$ & 0.069 \\
\hline Magnesium & $3.87 \pm 0.70$ & $6.06 \pm 0.30$ & 0.019 & $5.58 \pm 0.38$ & $6.08 \pm 0.41$ & 0.371 \\
\hline Sodium & $5.29 \pm 0.47$ & $6.08 \pm 0.35$ & 0.192 & $5.54 \pm 0.37$ & $6.18 \pm 0.43$ & 0.257 \\
\hline Copper & $5.00 \pm 0.71$ & $5.95 \pm 0.30$ & 0.249 & $5.50 \pm 0.63$ & $5.90 \pm 0.31$ & 0.576 \\
\hline Iron & $5.12 \pm 0.45$ & $6.18 \pm 0.35$ & 0.078 & $5.72 \pm 0.37$ & $5.97 \pm 0.43$ & 0.661 \\
\hline Manganese & $5.83 \pm 0.49$ & $5.82 \pm 0.34$ & 0.987 & $5.87 \pm 0.44$ & $5.80 \pm 0.36$ & 0.907 \\
\hline Selenium & a & a & a & a & a & $\mathrm{a}$ \\
\hline Zinc & $5.82 \pm 0.34$ & $5.84 \pm 0.48$ & 0.9731 & $5.86 \pm 0.32$ & $5.70 \pm 0.58$ & 0.815 \\
\hline
\end{tabular}

Legend: NRC Nutrient Requirements of Dogs and Cats [16], FEDIAF Fédération Européenne de I'Industrie des Aliments pour Animaux Familiers [15], SE standard error; ${ }^{1} \mathrm{Ca}$ calcium, $P$ phosphorus

${ }^{\text {a }}$ All diets had a deficiency of this nutrient

Table 2 Comparison of number of ingredients and nutrients per $1000 \mathrm{kcal}$ in diets for cats

\begin{tabular}{|c|c|c|c|c|c|c|}
\hline & \multicolumn{6}{|l|}{ Number of ingredients } \\
\hline & \multicolumn{3}{|l|}{ NRC } & \multicolumn{3}{|l|}{ FEDIAF } \\
\hline & $\begin{array}{l}\text { Mean ingredient number } \\
\text { of diets below }( \pm \text { SE) }\end{array}$ & $\begin{array}{l}\text { Mean ingredient number } \\
\text { of diets above }( \pm \text { SE) }\end{array}$ & $p$ & $\begin{array}{l}\text { Mean ingredient number } \\
\text { of diets below }( \pm \text { SE) }\end{array}$ & $\begin{array}{l}\text { Mean ingredient number } \\
\text { of diets above }( \pm S E)\end{array}$ & $p$ \\
\hline Crude protein & $4.33 \pm 1.20$ & $7.14 \pm 0.57$ & 0.097 & $4.50 \pm 0.87$ & $7.53 \pm 0.63$ & 0.022 \\
\hline Ether extract & $5.00 \pm 0.79$ & $7.75 \pm 0.70$ & 0.072 & $5.00 \pm 0.79$ & $7.65 \pm 0.67$ & 0.028 \\
\hline Calcium & $5.57 \pm 0.89$ & $7.28 \pm 0.64$ & 0.156 & $6.82 \pm 0.63$ & $6.75 \pm 0.92$ & 0.948 \\
\hline Phosphorus & $10.00 \pm 3.16$ & $6.67 \pm 0.53$ & 0.226 & $6.32 \pm 0.58$ & $8.33 \pm 1.18$ & 0.113 \\
\hline Ca: $P^{1}$ ratio & - & - & - & $5.70 \pm 0.76$ & $8.00 \pm 0.89$ & 0.166 \\
\hline Potassium & $6.40 \pm 0.57$ & $8.40 \pm 1.30$ & 0.140 & $6.96 \pm 0.54$ & $3.00 \pm 1.73$ & 0.162 \\
\hline Magnesium & $6.00 \pm 2.45$ & $6.83 \pm 0.53$ & 0.757 & $5.50 \pm 1.66$ & $6.91 \pm 0.55$ & 0.470 \\
\hline Sodium & $3.33 \pm 1.05$ & $7.27 \pm 0.57$ & 0.025 & $4.00 \pm 0.82$ & $7.68 \pm 0.64$ & 0.007 \\
\hline Copper & $4.00 \pm 2.00$ & $6.92 \pm 0.54$ & 0.290 & $6.00 \pm 1.73$ & $6.87 \pm 0.55$ & 0.655 \\
\hline Iron & $6.32 \pm 0.54$ & $10.33 \pm 1.85$ & 0.021 & a & $\mathrm{a}$ & a \\
\hline Manganese & $7.81 \pm 0.70$ & $5.00 \pm 0.75$ & 0.017 & $7.63 \pm 0.63$ & $4.17 \pm 0.83$ & 0.010 \\
\hline Selenium & $6.88 \pm 0.63$ & $6.62 \pm 0.91$ & 0.820 & $6.95 \pm 0.58$ & $6.00 \pm 1.22$ & 0.510 \\
\hline Zinc & $6.69 \pm 0.65$ & $7.00 \pm 0.88$ & 0.820 & $6.95 \pm 0.58$ & $6.00 \pm 1.22$ & 0.510 \\
\hline
\end{tabular}

Legend: NRC Nutrient Requirements of Dogs and Cats [16], FEDIAF Fédération Européenne de I'Industrie des Aliments pour Animaux Familiers [15], SE standard error; ${ }^{1} \mathrm{C} a$ calcium, $P$ phosphorus

${ }^{\text {a }}$ All diets had a deficiency of this nutrient

Non-supplemented canine and feline diets had calcium and calcium:phosphorus ratio $(\mathrm{Ca}: \mathrm{P})(p<0.05)$ below recommendations. Non-supplemented feline diets had lower sodium and iron, and zinc levels were below recommendations in both groups. The results regarding the influence of mineral supplementation in diets for dogs are presented in Table 3 and for cats in Table 4.

Twelve percent $(n=9 / 75)$ of recipes for dogs were vegetarian and $6.6 \%(n=5 / 75)$ were vegan, as they did not 
Table 3 Comparison of nutrient concentration per $1000 \mathrm{kcal}$ in diets for dogs with or without supplementation

\begin{tabular}{|c|c|c|c|c|c|}
\hline & \multirow{2}{*}{$\begin{array}{l}\text { NRC } \\
\text { (/1000 kcal) }\end{array}$} & \multirow{2}{*}{$\begin{array}{l}\text { FEDIAF } \\
(/ 1000 \text { kcal })\end{array}$} & \multicolumn{3}{|l|}{ Mineral supplementation } \\
\hline & & & $\begin{array}{l}\text { Diets without supplement } \\
( \pm \text { SD) }\end{array}$ & $\begin{array}{l}\text { Diets with supplement } \\
( \pm \text { SD) }\end{array}$ & $p$ \\
\hline Crude protein (g) & 25.00 & 52.10 & $93.05 \pm 34.64$ & $79.57 \pm 26.18$ & 0.0625 \\
\hline Ether extract (g) & 13.80 & 13.75 & $26.57 \pm 16.09$ & $30.46 \pm 16.03$ & 0.2312 \\
\hline Crude fiber (g) & - & - & $4.51 \pm 4.19$ & $4.19 \pm 3.25$ & 0.6322 \\
\hline Ash (g) & - & - & $3.33 \pm 1.13$ & $5.80 \pm 3.92$ & $<0.0001$ \\
\hline Calcium (g) & 1.00 & 1.45 & $0.31 \pm 0.31$ & $1.77 \pm 1.52$ & $<0.0001$ \\
\hline Phosphorus (g) & 0.75 & 1.16 & $1.16 \pm 0.77$ & $1.09 \pm 0.61$ & 0.1737 \\
\hline Ca:P' ratio & - & 1.00 & $0.26 \pm 0.22$ & $1.78 \pm 1.46$ & $<0.0001$ \\
\hline Potassium (g) & 1.00 & 1.45 & $0.77 \pm 0.33$ & $0.85 \pm 0.46$ & 0.2923 \\
\hline Magnesium (g) & 0.15 & 0.20 & $0.25 \pm 0.11$ & $0.19 \pm 0.11$ & 0.0844 \\
\hline Sodium (g) & 0.20 & 0.29 & $0.35 \pm 0.29$ & $0.51 \pm 0.49$ & 0.4390 \\
\hline Copper (mg) & 1.50 & 2.08 & $7.30 \pm 6.23$ & $11.61 \pm 12.37$ & 0.1099 \\
\hline Iron (mg) & 7.50 & 10.40 & $9.59 \pm 5.02$ & $15.34 \pm 12.25$ & 0.1228 \\
\hline Manganese (mg) & 1.20 & 1.67 & $3.23 \pm 2.69$ & $3.96 \pm 4.09$ & 0.8873 \\
\hline Selenium ( $\mu \mathrm{g})$ & 87.50 & 87.00 & $1.53 \pm 7.02^{\mathrm{a}}$ & $0.00 \pm 0.00^{\mathrm{a}}$ & 0.5085 \\
\hline Zinc (mg) & 15.00 & 20.80 & $11.13 \pm 6.93$ & $14.98 \pm 10.93$ & 0.2592 \\
\hline
\end{tabular}

Legend: NRC recommended intake according to Nutrient Requirements of Dogs and Cats [16], FEDIAF recommended intake according to Fédération Européenne de I'Industrie des Aliments pour Animaux Familiers [15], SD standard deviation; ${ }^{1} \mathrm{C} a$ calcium, $P$ phosphorus

${ }^{a}$ All diets had a deficiency of this nutrient

Table 4 Comparison of nutrient concentration per $1000 \mathrm{kcal}$ in diets for cats with or without supplementation

\begin{tabular}{|c|c|c|c|c|c|}
\hline & \multirow{2}{*}{$\begin{array}{l}\text { NRC } \\
(/ 1000 \text { kcal })\end{array}$} & \multirow{2}{*}{$\begin{array}{l}\text { FEDIAF } \\
\text { (/1000 kcal) }\end{array}$} & \multicolumn{3}{|l|}{ Mineral supplementation } \\
\hline & & & $\begin{array}{l}\text { Diets without supplement } \\
( \pm \text { SD) }\end{array}$ & $\begin{array}{l}\text { Diets with supplement } \\
( \pm \text { SD) }\end{array}$ & $p$ \\
\hline Crude protein (g) & 50.00 & 83.30 & $97.66 \pm 57.37$ & $142.52 \pm 41.41$ & 0.0605 \\
\hline Ether extract (g) & 22.50 & 22.50 & $34.64 \pm 23.67$ & $33.56 \pm 15.03$ & 0.9050 \\
\hline Crude fiber (g) & - & - & $5.81 \pm 4.51$ & $3.36 \pm 3.07$ & 0.4203 \\
\hline Ash (g) & - & - & $4.56 \pm 2.03$ & $6.20 \pm 1.33$ & 0.0114 \\
\hline Calcium (g) & 0.72 & 1.97 & $0.70 \pm 0.70$ & $2.26 \pm 1.22$ & 0.0011 \\
\hline Phosphorus (g) & 0.64 & 1.67 & $1.29 \pm 0.39$ & $1.33 \pm 0.51$ & 0.6827 \\
\hline Ca:P' ratio & - & 1.00 & $0.50 \pm 0.38$ & $2.26 \pm 2.19$ & 0.0002 \\
\hline Potassium (g) & 1.30 & 2.00 & $1.00 \pm 0.52$ & $1.07 \pm 0.36$ & 0.7207 \\
\hline Magnesium (g) & 0.10 & 0.13 & $0.27 \pm 0.11$ & $0.23 \pm 0.07$ & 0.2521 \\
\hline Sodium (g) & 0.17 & 0.25 & $0.46 \pm 0.36$ & $0.78 \pm 0.41$ & 0.0458 \\
\hline Copper (mg) & 1.20 & 1.67 & $7.23 \pm 8.21$ & $15.53 \pm 12.88$ & 0.0613 \\
\hline Iron (mg) & 20.00 & 26.70 & $10.19 \pm 3.47$ & $15.51 \pm 5.55$ & 0.0095 \\
\hline Manganese (mg) & 1.20 & 1.67 & $3.63 \pm 4.98$ & $1.65 \pm 3.14$ & 0.3042 \\
\hline Selenium $(\mu \mathrm{g})$ & 75.00 & 100.00 & $20.70 \pm 62.10^{a}$ & $0.00 \pm 0.00^{\mathrm{a}}$ & 0.4000 \\
\hline Zinc (mg) & 18.50 & 25.00 & $10.27 \pm 5.52$ & $19.51 \pm 8.19$ & 0.0037 \\
\hline
\end{tabular}

Legend: NRC recommended intake according to Nutrient Requirements of Dogs and Cats [16], FEDIAF recommended intake according to Fédération Européenne de I'Industrie des Aliments pour Animaux Familiers [15], SD standard deviation; ${ }^{1} \mathrm{Ca}$ calcium, $P$ phosphorus

${ }^{\text {a } A l l ~ d i e t s ~ h a d ~ a ~ d e f i c i e n c y ~ o f ~ t h i s ~ n u t r i e n t ~}$

contain ingredients from animal sources. As for the recipes for cats, $4.0 \%(n=1 / 25)$ were vegetarian and $8.0 \%$ $(n=2 / 25)$ were vegan.
Protein and zinc were increased in non-vegetarian diets for dogs, although zinc was deficient in both groups. There were higher amounts of crude fiber, magnesium, 
and manganese in vegetarian and vegan diets $(p<0.05)$. Protein was increased in non-vegetarian diets for cats $(p=0.003)$, but there was a higher amount of crude fiber $(p=0.014)$ in vegetarian and vegan diets. The results regarding the influence of preparations with or without animal products in diets for dogs are presented in Table 5 and for cats in Table 6.

\section{Discussion}

This study evaluated if three factors can influence the nutritional composition of diets: number of ingredients, presence of mineral or vitamin-mineral supplements, and the fact that the recipe is vegetarian or vegan.

The number of ingredients influenced the concentration of macro and micronutrients, especially in recipes for cats. For dogs, differences were only observed in fat and magnesium, for which recipes that met NRC [16] and FEDIAF [15] recommendations had more ingredients than diets below the recommendations. In recipes for cats, sodium, iron, crude protein, and fat had lower concentrations in recipes with fewer ingredients when compared to NRC [16] and FEDIAF [15]. These differences suggest that, for some nutrients, more ingredients in the recipe can be beneficial. However, even recipes that contained more nutrients were not completely balanced, which means that having recipes with more ingredients does not guarantee a balanced diet.
A study conducted by Dodd et al. [9] observed that $16.3 \%$ of owners who responded to the questionnaire were interested in feeding plant-based diets, and $74.0 \%$ of all owners included were concerned about the nutritional adequacy of plant-based diets. Vegetarian and vegan diets had little difference when compared to recipes that contained meat regarding the macronutrient and mineral analyses in the present study. However, none of the diets were complete, which may have influenced the results. The fact that a diet for dogs and cats is vegetarian or vegan does not mean that the food is inadequate, as long as it is well balanced and formulated to supply all essential nutrients [17]. For cats, however, there are several limitations to this type of diet, especially vegan. Cats have requirements of dietary taurine since they do not synthesize it in amounts sufficient to a proper metabolism $[18,19]$. This supplementation must be given special attention when a diet doesn't contain animal proteins because vegetable proteins have little or no taurine concentration at all [20]. Other nutrients, such as cobalamin, retinol, arachidonic acid, and cholecalciferol must be supplemented in diets with only vegetable ingredients since they are present mainly or exclusively in animal products $[16,19,21]$. Even commercial vegan diets have been analyzed and were considered inadequate for both dogs and cats $[20,22]$.

In the present study, vegetarian and vegan diets for dogs and cats presented lower concentrations of crude

Table 5 Comparison of nutrient concentration per $1000 \mathrm{kcal}$ in diets for dogs with meat or vegetarian/vegan

\begin{tabular}{|c|c|c|c|c|c|}
\hline & \multirow{2}{*}{$\begin{array}{l}\text { NRC } \\
\text { (/1000 kcal) }\end{array}$} & \multirow{2}{*}{$\begin{array}{l}\text { FEDIAF } \\
\text { (/1000 kcal) }\end{array}$} & \multicolumn{3}{|c|}{ Presence of meat and animal products } \\
\hline & & & Diets with meat $( \pm S D$ ) & $\begin{array}{l}\text { Vegetarian and vegan } \\
\text { diets }( \pm \text { SD) }\end{array}$ & $p$ \\
\hline Crude protein (g) & 25.00 & 52.10 & $94.83 \pm 29.75$ & $52.41 \pm 15.56$ & $<0.0001$ \\
\hline Ether extract (g) & 13.80 & 13.75 & $28.42 \pm 15.15$ & $27.02 \pm 20.36$ & 0.6352 \\
\hline Crude fiber (g) & - & - & $3.97 \pm 3.85$ & $6.31 \pm 3.11$ & 0.0034 \\
\hline Ash (g) & - & - & $4.34 \pm 3.07$ & $4.41 \pm 2.14$ & 0.8007 \\
\hline Calcium (g) & 1.00 & 1.45 & $0.81 \pm 1.04$ & $1.38 \pm 1.85$ & 0.1088 \\
\hline Phosphorus (g) & 0.75 & 1.16 & $1.13 \pm 0.45$ & $1.14 \pm 0.41$ & 0.8887 \\
\hline Ca:P' ratio & - & 1.00 & $0.84 \pm 1.22$ & $1.09 \pm 1.16$ & 0.1581 \\
\hline Potassium (g) & 1.00 & 1.45 & $0.80 \pm 0.41$ & $0.83 \pm 0.25$ & 0.7216 \\
\hline Magnesium (g) & 0.15 & 0.20 & $0.21 \pm 0.11$ & $0.28 \pm 0.11$ & 0.0475 \\
\hline Sodium (g) & 0.20 & 0.29 & $0.42 \pm 0.37$ & $0.44 \pm 0.48$ & 0.8329 \\
\hline Copper (mg) & 1.50 & 2.08 & $8.98 \pm 9.75$ & $9.57 \pm 8.29$ & 0.6918 \\
\hline Iron (mg) & 7.50 & 10.40 & $12.14 \pm 9.90$ & $11.13 \pm 4.58$ & 0.5748 \\
\hline Manganese (mg) & 1.20 & 1.67 & $3.31 \pm 3.45$ & $4.62 \pm 2.62$ & 0.0356 \\
\hline Selenium $(\mu \mathrm{g})$ & 87.50 & 87.00 & $0.58 \pm 4.51^{\mathrm{a}}$ & $2.42 \pm 8.39^{\mathrm{a}}$ & 0.3186 \\
\hline Zinc (mg) & 15.00 & 20.80 & $13.86 \pm 9.43$ & $7.27 \pm 2.92$ & 0.0327 \\
\hline
\end{tabular}

Legend: NRC recommended intake according to Nutrient Requirements of Dogs and Cats [16], FEDIAF recommended intake according to Fédération Européenne de I'Industrie des Aliments pour Animaux Familiers [15], SD standard deviation; ${ }^{1} \mathrm{C} a$ calcium, $P$ phosphorus

${ }^{\text {a }}$ All diets had a deficiency of this nutrient 
Table 6 Comparison of nutrient concentration per $1000 \mathrm{kcal}$ in diets for cats with meat or vegetarian/vegan

\begin{tabular}{|c|c|c|c|c|c|}
\hline & \multirow{2}{*}{$\begin{array}{l}\text { NRC } \\
(/ 1000 \text { kcal })\end{array}$} & \multirow{2}{*}{$\begin{array}{l}\text { FEDIAF } \\
\text { (/1000 kcal) }\end{array}$} & \multicolumn{3}{|c|}{ Presence of meat and animal products } \\
\hline & & & Diets with meat $( \pm S D)$ & $\begin{array}{l}\text { Vegetarian and vegan } \\
\text { diets }( \pm \text { SD) }\end{array}$ & $p$ \\
\hline Crude protein (g) & 50.00 & 83.30 & $135.71 \pm 46.40$ & $42.92 \pm 14.31$ & 0.0035 \\
\hline Ether extract (g) & 22.50 & 22.50 & $33.94 \pm 14.56$ & $34.34 \pm 37.99$ & 0.4052 \\
\hline Crude fiber (g) & - & - & $3.44 \pm 3.03$ & $10.89 \pm 3.32$ & 0.0139 \\
\hline Ash (g) & - & - & $5.47 \pm 1.67$ & $6.11 \pm 2.67$ & 0.9113 \\
\hline Calcium (g) & 0.72 & 1.97 & $1.76 \pm 1.33$ & $0.70 \pm 0.32$ & 0.2730 \\
\hline Phosphorus (g) & 0.64 & 1.67 & $1.34 \pm 0.47$ & $1.13 \pm 0.35$ & 0.4457 \\
\hline Ca:P' ratio & - & 1.00 & $1.69 \pm 2.01$ & $0.60 \pm 0.08$ & 0.2130 \\
\hline Potassium (g) & 1.30 & 2.00 & $1.01 \pm 0.37$ & $1.30 \pm 0.67$ & 0.4909 \\
\hline Magnesium (g) & 0.10 & 0.13 & $0.23 \pm 0.06$ & $0.34 \pm 0.19$ & 0.4035 \\
\hline Sodium (g) & 0.17 & 0.25 & $0.70 \pm 0.42$ & $0.30 \pm 0.20$ & 0.0870 \\
\hline Copper (mg) & 1.20 & 1.67 & $12.31 \pm 11.90$ & $11.49 \pm 12.39$ & 0.6696 \\
\hline Iron (mg) & 20.00 & 26.70 & $13.47 \pm 5.61$ & $12.71 \pm 4.43$ & 0.9613 \\
\hline Manganese (mg) & 1.20 & 1.67 & $1.58 \pm 2.69$ & $8.77 \pm 6.41$ & 0.2004 \\
\hline Selenium ( $\mu \mathrm{g})$ & 75.00 & 100.00 & $0.00 \pm 0.00$ & $69.00 \pm 97.58$ & 0.1200 \\
\hline Zinc (mg) & 18.50 & 25.00 & $16.48 \pm 8.67$ & $10.91 \pm 5.32$ & 0.2800 \\
\hline
\end{tabular}

Legend: NRC recommended intake according to Nutrient Requirements of Dogs and Cats [16], FEDIAF recommended intake according to Fédération Européenne de I'Industrie des Aliments pour Animaux Familiers [15], SD standard deviation; ${ }^{1} C a$ calcium, $P$ phosphorus

${ }^{a}$ All diets had a deficiency of this nutrient

protein and higher concentrations of crude fiber than diets with meats. The lower protein levels of these diets may be due to the higher inclusion of vegetable ingredients that may not necessarily be selected based on protein content $[16,23,24]$. The higher zinc concentrations in meat-containing preparations for dogs were expected since this nutrient is present in greater quantities in animal products, especially meats and offal [23]. Furthermore, phytate present in vegetable ingredients can bind to zinc and reduce its bioavailability, which may increase the potential for zinc deficiency [25]. The levels of manganese, magnesium, and crude fiber were higher in vegetarian and vegan preparations, which can be explained by the fact that these nutrients are present in higher amounts in vegetable products [23].

The presence of mineral and vitamin-mineral supplements was also evaluated in the present study. In recipes for dogs, the concentrations of ash and calcium and the calcium:phosphorus ratio were lower in recipes without mineral supplementation. In recipes for cats, the concentrations of ash, calcium, sodium, and iron, and the calcium:phosphorus ratio were lower in diets without mineral supplementation. The higher calcium concentrations in recipes with mineral supplements were expected since most diets contained at least one calcium-rich supplement such as vitamin-mineral supplements, calcium carbonate, and eggshell powder. According to the results of this study, it can be suggested that the presence of a supplement alone does not guarantee a balanced diet because none of the diets were complete regardless of the inclusion of supplements. This is an important result since it demonstrates that a diet should be formulated as a whole, considering the inclusion of all ingredients and their combination of nutrients, including the supplement. Even when a multi-mineral supplement was added according to the manufacturer's instructions, the diets remained unbalanced.

\section{Conclusions}

In the present study, none of the recipes evaluated supplied all nutrients analyzed, including protein, fat, and essential minerals. The number of ingredients did not expressively influence the nutritional composition of diets, as well as a vegetarian or vegan preparation. The presence of supplement on its own does not ensure a balanced diet for dogs and cats. If a food is to be properly formulated the nutritionist must consider the target species and the nutritional profile of all ingredients including those used in supplementation.

\section{Materials and methods}

\section{Selection of recipes}

Recipes for healthy adult dogs and cats published in Portuguese were searched with the terms "home-prepared diet", "home-cooked diet", "homemade food", "homeprepared diet recipe", "home-cooked diet recipe" and 
"homemade food recipe", all followed by the terms "dog" or "cat", in the Google browser. The Recipes up until the 10th page of the browser for each search term were included.

The exclusion criteria were: the same recipe presented in more than one website; recipes not clearly stated for healthy adults; recipes stated not for daily use; recipes considered by its author as a snack or milk replacer; and if amounts of one or more ingredients were not specified. After applying exclusion criteria, 75 recipes for dogs and 25 recipes for cats were randomly selected using a random drawing generator.

\section{Preparation of recipes}

Ingredients were acquired from three different markets in the city of Sao Paulo, Brazil, and preference was given to fresh foods. Preparation of samples with $500 \mathrm{~g}$ for each recipe was done according to recipe's instructions, considering ingredients, quantities of ingredients, and cooking mode (i.e. raw, boiled, or baked).

For each recipe, all ingredients were prepared, weighed in a digital cooking scale, and then blended with the use of a food processor. When recipes indicated units of an ingredient instead of weight, USDA FoodData Central [23] measures were used. If a vitamin-mineral supplement was indicated in the recipe but there was no specification of brand or amount, a commercial product for homemade diets (Food Dog Adulto Manutenção, Botupharma, Botucatu, Brazil) was used considering the manufacturer's recommended amount.

\section{Chemical analyses}

The recipe's samples were dehydrated in a forced circulation oven at $55^{\circ} \mathrm{C}$ for $72 \mathrm{~h}$ [26], and then were ground and a subsample was put in a forced circulation oven at $105^{\circ} \mathrm{C}$ to determine dry matter content. Crude protein analyses were performed by the Kjeldahl method, crude fat was determined by the Soxhlet method, and ash content was determined by incineration at $550^{\circ} \mathrm{C}[26,27]$. The crude fiber content was determined by the Weende method [28]. Nitrogen-free extract (NFE) was calculated by subtracting ash, crude fiber, crude protein, and crude fat percentages out of $100 \mathrm{~g}$ of dry matter [16]. The chemical analyses were performed in duplicate at the Multiuser Laboratory of Animal Nutrition and Bromatology of the School of Veterinary Medicine and Animal Science of the University of Sao Paulo (Pirassununga, Brazil).

\section{Mineral analyses}

Closed vessel microwave digestion was used to process samples for mineral analyses at the laboratory of Biorigin Brazil (Lençóis Paulista, Brazil). After dehydration, samples of $0.5 \mathrm{~g}$ of each recipe were placed in polypropylene tubes, and $1.5 \mathrm{~mL}$ of $\mathrm{HNO}_{3}$ and $2 \mathrm{~mL}$ of hydrogen peroxide $\left(\mathrm{H}_{2} \mathrm{O}_{2}\right)$ were added to each tube, which was left to rest for $30 \mathrm{~min}$. After resting, $4.5 \mathrm{~mL}$ of ultrapure water was added to each sample. The tubes were then placed in a microwave (Multiwave GO, Anton Parr, Graz, Austria) and were heated in two phases. In the first phase, the samples were heated for $20 \mathrm{~min}$ until reaching $180^{\circ} \mathrm{C}$ at $400 \mathrm{~W}$. In the second phase, the samples were heated for $10 \mathrm{~min}$ at $180^{\circ} \mathrm{C}$ and $800 \mathrm{~W}$. After the second phase, the samples were left to cool for $10 \mathrm{~min}$.

The analyses of minerals were performed in triplicate by inductively coupled plasma optical emission spectrometry [ICP-OES (ICPE-9000, Shimadzu of Brazil, Barueri, Brazil)] at the Multiuser Laboratory of Animal Nutrition and Bromatology of the Department of Nutrition and Animal Production of the School of Veterinary Medicine and Animal Science of University of Sao Paulo (Pirassununga, Brazil). Operational conditions are presented in Table 7.

Preparation of external calibration curves was done by using multielement standard solutions at concentrations of $100 \mathrm{mg} / \mathrm{L}$ for calcium $(\mathrm{Ca})$, copper $(\mathrm{Cu})$, iron $(\mathrm{Fe})$, mercury $(\mathrm{Hg})$, potassium $(\mathrm{K})$, magnesium $(\mathrm{Mg})$, manganese $(\mathrm{Mn})$, sodium $(\mathrm{Na})$, phosphorus $(\mathrm{P})$, selenium $(\mathrm{Se})$, and zinc ( $\mathrm{Zn})$ (SpecSol, Quimilab, Jacareí, Brazil). The curves were prepared in a range of concentrations from 0.1 to $5 \mathrm{mg} / \mathrm{L}$ for $\mathrm{Cu}, \mathrm{Zn}, \mathrm{Na}$, and $\mathrm{Mn}$, from 0.5 to $100 \mathrm{mg} / \mathrm{L}$ for $\mathrm{Ca}, \mathrm{P}, \mathrm{Mg}$, and $\mathrm{K}$, and from 0.001 to $2 \mathrm{mg} / \mathrm{L}$ for Fe and Se. For the determination of selenium, a hydride generator (hydrideICP, Elemental Scientific, Omaha, United States) was coupled to the ICP-OES.

\section{Conversion of data from dry matter to caloric basis}

Based on the results of the analysis of macronutrients, the Atwater method was used to calculate the metabolizable energy of the diets [16], considering $4 \mathrm{kcal}$ per gram of crude protein and NFE and $9 \mathrm{kcal}$ per gram of crude fat [29]. After determining the energy of each diet, the results were converted from unit/100g of

Table 7 Operational conditions of inductively coupled plasma optical emission spectrometry (ICP-OES) with axial configuration

\begin{tabular}{ll}
\hline Parameter & Characteristics \\
\hline Radiofrequency power $(\mathrm{W})$ & 1200 \\
Plasma gas flow rate $(\mathrm{L} / \mathrm{min})$ & 10 \\
Auxiliary gas flow rate $(\mathrm{L} / \mathrm{min})$ & 0.6 \\
Sample uptake rate $(\mathrm{s})$ & 30 \\
Nebulizer gas flow rate $(\mathrm{L} / \mathrm{min})$ & 0.7 \\
Nebulizer type & Concentric \\
Spray chamber & Cyclone \\
Replicates & 3 \\
\hline
\end{tabular}


dry matter to unit $/ 1000 \mathrm{kcal}$ of metabolizable energy according to the equation:

$$
\text { Nutrient } / 1000 \mathrm{kcal}=\frac{1000 \times \text { nutrient amount per } 100 \mathrm{~g} \text { dry matter }}{\text { Metabolizable energy per } 100 \mathrm{~g} \text { dry matter }}
$$

\section{Statistical analyses}

The Shapiro-Wilk test was used to test the normality of variables. For normally distributed variables, Student's t-test was used to evaluate significance between the results and NRC [16] and FEDIAF [15] nutritional recommendations. For variables with non-normal distribution, the Mann-Whitney test was used. For the analyses of the influence of the number of ingredients on composition, a generalized linear model was used, considering the number of ingredients as Poisson distribution and the log link function. The means and standard errors were detransformed using the TukeyKramer test. NRC [16] and FEDIAF [15] recommendations for adult dogs and cats for $1000 \mathrm{kcal}$ were used considering daily energy intakes of $95 \mathrm{kcal} / \mathrm{kg}^{0.75}$ for dogs and $75 \mathrm{kcal} / \mathrm{kg}^{0.67}$ for cats, both equations referring to inactive animals.

Data were analyzed using SAS version 9.4 (SAS Institute, NC, USA) and statistical significance was accepted if $p \leq 0.05$.

\section{Abbreviations \\ FEDIAF: Fédération Européenne de l'Industrie des Aliments pour Animaux Familiers; NFE: Nitrogen-free extract; NRC: National Research Council's Nutri- ent Requirements of Dogs and Cats; USDA: United States Department of Agriculture.}

\section{Acknowledgements}

The authors would like to thank Grandfood Industry and Commerce Ltd. (PremieR pet) for funding our Pet Nutrology Research Center, Biorigin Brazil for conducting the microwave digestion process, and the National Council for Scientific and Technological Development for funding the scholarship of the first author (process 88882.376854/2019-01).

\section{Authors' contributions \\ The study design was performed by V.P. and M.A.B. All authors participated in the manuscript writing and review process. Laboratory analyses were per- formed by V.P., R.V.A.Z., R.B.A.R., M.P.P. and R.M.C.C. The statistical analyses were performed by J.C.C.B. The author(s) read and approved the final manuscript.}

\section{Funding}

There was no specific funding or grant for this research.

\section{Availability of data and materials}

The results for all analyzed diets that support the findings of this study are available in Scientific Reports with the identifier(s) https://doi.org/10.1038/ s41598-019-49087-z [10].

\section{Declarations}

Ethics approval and consent to participate Not applicable.
Consent for publication

Not applicable.

\section{Competing interests}

The authors declare that they have no competing interests.

\begin{abstract}
Author details
${ }^{1}$ Veterinary Nutrology Service, Veterinary Teaching Hospital, School of Veterinary Medicine and Animal Science, University of Sao Paulo, Avenida Professor Orlando Marques de Paiva, 87, Sao Paulo 05508-270, Brazil. ${ }^{2}$ Pet Nutrology Research Center, Nutrition and Production Department, School of Veterinary Medicine and Animal Science, University of Sao Paulo, Avenida Duque de Caxias Norte, 255, Pirassununga 13635-900, Brazil. ${ }^{3}$ Department of Animal Nutrition and Production, School of Veterinary Medicine and Animal Science, University of Sao Paulo, Avenida Duque de Caxias Norte, 255, Pirassununga 13635-900, Brazil.
\end{abstract}

Received: 12 July 2021 Accepted: 26 October 2021

Published online: 20 November 2021

\section{References}

1. Laflamme DP, Abood SK, Fascetti AJ, Fleeman LM, Freeman LM, Michel $\mathrm{KE}$, et al. Pet feeding practices of dog and cat owners in the United States and Australia. J Am Vet Med Assoc. 2008;232(5):687-94. https://doi.org/ 10.2460/javma.232.5.687.

2. Dodd SAS, Cave NJ, Verbrugghe A. Changes in the feeding practices of domestic dogs and cats over the last decade. In: ESVCN Proceedings 2018. Munique: Alemanha: ESVCN; 2018. p. 227.

3. Freeman LM, Becvarova I, Cave NJ, MacKay C, Nguyen P, Rama B, et al. Nutritional Assessment Guidelines. J Small Anim Pract. 2011;00:1-12. https://doi.org/10.1111/j.1748-5827.2011.01079.x.

4. IBOPE Inteligência. Pesquisa de opinião pública sobre vegetarianismo [Internet]. 2018

5. Gallup. Consumption Habits [Internet]. Gallup Poll Social Series. 2018.

6. The Vegan Society. Statistics. 2020. [cited 2020 Jun 18].

7. Government of India. Sample Registration System Baseline Survey 2014 [Internet]. Census. 2014.

8. Fox N, Ward K. Health, ethics and environment: a qualitative study of vegetarian motivations. Appetite. 2008;50:422-9. https://doi.org/10.1016/j. appet.2007.09.007.

9. Dodd SAS, Cave NJ, Adolphe JL, Shoveller AK, Verbrugghe A. Plant-based (vegan) diets for pets: a survey of pet owner attitudes and feeding practices. PLoS One. 2019;14(1):e0210806. https://doi.org/10.1371/journ al.pone.0210806.

10. Pedrinelli V, Zafalon RVA, Rodrigues RBA, Perini MP, Conti RMC, Vendramini THA, et al. Concentrations of macronutrients, minerals and heavy metals in home-prepared diets for adult dogs and cats. Sci Rep. 2019;9(1):1-12. https://doi.org/10.1038/s41598-019-49087-z.

11. Stockman J, Fascetti AJ, Kass PH, Larsen JA. Evaluation of recipes of home-prepared maintenance diets for dogs. J Am Vet Med Assoc. 2013;242(11):1500-5. https://doi.org/10.2460/javma.242.11.1500.

12. Johnson LN, Linder DE, Heinze CR, Kehs RL, Freeman LM. Evaluation of owner experiences and adherence to home-cooked diet recipes for dogs. J Small Anim Pract. 2016;57(1):23-7. https://doi.org/10.1111/jsap. 12412.

13. Oliveira MC de C, Brunetto MA, da Silva FL, Jeremias JT, Tortola L, de OS $G M$, et al. Evaluation of the owner's perception in the use of homemade diets for the nutritional management of dogs. J Nutr Sci. 2014;3(e23):1-5. https://doi.org/10.1017/jns.2014.24.

14. Remillard RL, Crane SW. Making pet foods at home. In: Small animal clinical nutrition. 5th ed. Topeka: Mark Morris Institute; 2010. p. 207-23.

15. FEDIAF. Nutritional guidelines for complete and complementary pet food for cats and dogs. Brussels: Fédération Européenne de l'Industrie des Aliments pour Animaux Familiers; 2019. p. 96.

16. NRC. Nutrient Requirements of Dogs and Cats. In: National Research Council. 1st ed. Washington, D.C.: National Academy Press; 2006. p. 398.

17. Parr JM, Remillard RL. Handling alternative dietary requests from pet owners. Vet Clin North Am Small Anim Pract. 2014;44:667-88. https://doi.org/ 10.1016/j.cvsm.2014.03.006. 
18. Armstrong PJ, Gross KL, Becvarova I, Debraekeleer J. Introduction to feeding normal cats. In: Hand MS, Thatcher CD, Remillard RL, Roudebush P Novotny BJ, editors. Small Animal Clinical Nutrition. 5th ed. Topeka: Mark Morris Institute; 2010. p. 361-72.

19. MacDonald ML, Rogers QR, Morris JG. Nutrition of the domestic cat, a mammalian carnivore. Annu Rev Nutr. 1984;4:521-62.

20. Gray CM, Sellon RK, Freeman LM. Nutritional adequacy of two vegan diets for cats. J Am Vet Med Assoc. 2004;225(11):1670-5. https://doi.org/10. 2460/javma.2004.225.1670.

21. Morris JG. Cats discriminate between cholecalciferol and ergocalciferol. J Anim Physiol Anim Nutr (Berl). 2002;86:229-38.

22. Zafalon RVA, Risolia LW, Vendramini THA, Rodrigues RBA, Pedrinelli V, Teixeira FA, et al. Nutritional inadequacies in commercial vegan foods for dogs and cats. PLoS One. 2020;15(e0227046):1-17. https://doi.org/10. 1371/journal.pone.0227046.

23. USDA. National Nutrient Database for Standard Reference [Internet]. National Nutrient Database for Standard Reference. 2018. [cited 2018 Feb 3].

24. Michel KE. Unconventional diets for dogs and cats. Vet Clin North Am Small Anim Pract. 2006;36:1269-81. https://doi.org/10.1016/j.cvsm.2006. 08.003 .
25. Hambidge KM, Casey CE, Krebs NF. Zinc. In: Mertz W, editor. Trace Elements in Human and Animal Nutrition -Volume 2. 5th ed. San Diego: Academic Press; 1986. p. 499.

26. AOAC. Official methods of analysis. Association of the Official Analytical Chemists, editor. AOAC International: Gaithersburg; 2006.

27. AOAC. Official methods of analysis. 16th ed. Association of the Official Analytical Chemists, editor. AOAC International: Arlington; 1995.

28. Williams RD, Olmsted WH. A biochemical method for determining indigestible residue (crude fiber) in feces: lignin, cellulose, and non-water soluble hemicelluloses. J Biol Chem. 1935;108(3):635-66.

29. Atwater WO. Principles of nutrition and nutritive value of food. Vol. 142, Farmer's bulletin. Washington, D.C: United States Department of Agriculture; 1902 . p. 48.

30. USDA. Food Data Central [Internet]. Food Data Central. 2020 [cited 2020 Jan 21].

\section{Publisher's Note}

Springer Nature remains neutral with regard to jurisdictional claims in published maps and institutional affiliations.
Ready to submit your research? Choose BMC and benefit from:

- fast, convenient online submission

- thorough peer review by experienced researchers in your field

- rapid publication on acceptance

- support for research data, including large and complex data types

- gold Open Access which fosters wider collaboration and increased citations

- maximum visibility for your research: over $100 \mathrm{M}$ website views per year

At BMC, research is always in progress.

Learn more biomedcentral.com/submissions 